\title{
Evaluation of Lung Cancer Patients with Distant Organ Metastasis*
}

\author{
Uzak Organ Metastazlı Akciğer Kanseri Hastalarının Değerlendirilmesi ${ }^{\star \star}$
}

\author{
Pınar Acar', Meftun Ünsal', Nejat Altıntaș ${ }^{1}$ \\ ${ }^{1}$ On Dokuz Mayıs University Faculty of Medicine, Samsun; ${ }^{2}$ Namık Kemal University Faculty of Medicine, Tekirdă̆
}

\begin{abstract}
AIM: Cancer is the leading cause of death in economically developed countries and the second leading cause of death in developing countries. The aim of the study was to evaluate distant organ metastasis in patients with lung cancer and the effect of metastasis on survival rates.
\end{abstract}

METHODS: Lung cancer patients with distant organ metastasis were enrolled to the study. Localization of primary tumors and metastasis, histological types of the metastasis, clinical symptoms and signs, the interaction of tumor and lymph nodes, the effects of metastasis on survival rates were evaluated.

RESULTS: 174 patients were included in the study. Cytologic subgroups of patients were subdivided as non-small cell lung cancer (NSCLC) (75.3\%) and small cell lung cancer (SCLC) (24.7\%). The most frequent metastatic sites were bone (41.4\%), contralateral lung (32.8\%), liver (23.9\%) brain (27\%), adrenal gland (19,5\%), pleura (9.2\%). The most common metastasis sites for NSCLC and SCLC were bone and liver respectively. Squamous cell carcinoma was the most common type of metastases in brain, bone, adrenal and contralateral lung metastasis. Metastatic pleural effusions mostly originated from adenocarcinoma and liver metastasis generally originated from small cell lung cancer. Having specific symptoms related to bone and brain were powerful predictors for metastasis.

CONCLUSION: Cytological types of the cancer, number of metastasis, weight loss, poor performance status, the absence of symptoms in SCLC with bone and brain metastasis, and presence of the symptoms in liver metastases had adverse effects on survival rates. Evaluation of patients with combination of clinical symptoms, laboratory and radiological findings as whole it may be helpful in predicting metastasis and may prevent unnecessary surgery.

Key words: lung cancer; metastasis; symptoms; laboratory; survival

* Accepted as a poster presentation in ERS 2014 Munich/Germany congress.

**ERS 2014 Kongresinde (Münih/Almanya) sunulan bir poster.

Yard. Doç. Dr. Nejat Altıntaş, Namık Kemal University, Department of Pulmonary, Critical Care and Sleep Medicine, Tekirdă̆, Türkiye Tel.02825000000Email.nejataltintas@gmail.com

Geliş Taribi: 22.09.2015 • Kabul Taribi: 26.11.2015

\section{ÖZET}

AMAÇ: Kanser ekonomik olarak gelișmiș ülkelerde önde gelen ölüm nedenidir ve gelișmekte olan ülkelerde ikinci önde gelen ölüm nedenidir. Çalıșmanın amacı, uzak organ metastaz olan akciğer kanserli hastaların ve metastazların sağkalım oranları üzerine etkisinin değerlendirilmesidir.

YÖNTEM: Uzak organ metastazı olan akciğer kanserli hastalar çalıșmaya alındı. Primer tümörlerin lokalizasyonu ve metastaz, metastaz histolojik tipleri, klinik belirti ve bulgular, tümör ve lenf nodlarının etkileșimi, sağkalım oranları üzerindeki metastazların etkisi değerlendirildi.

BULGULAR: Çalıșmaya 174 hasta dahil edildi. Hastaların sitolojik alt gruplarının küçük hücreli dıșı akciğer kanseri (KHDAK) $(\% 75,3)$ ve küçük hücreli akciğer kanseri (KHAK) $(\% 24,7)$ olarak iki alt gruba ayrıldı. En sık metastaz bölgleri kemik $(\% 41,4)$, kontralateral akciğer $(\% 32,8)$, karaciğer (\%23,9) beyin (\%27), böbreküstü bezi $(\% 19,5)$, plevra $(\% 9,2)$ idi. KHDAK ve KHAK için en sık metastaz yerleri sırasılyla kemik ve karaciğer idi. Skuamöz hücreli karsinom beyin, kemik, böbreküstü ve karșı akciğerde metastaz en yaygın türü oldu. Metastatik plevra sıvıları çoğunlukla genellikle adenokarsinom ve karaciğer metastazları ise küçük hücreli akciğer kanserlerinde kaynaklanmıștır. Kemik ve beyin ile ilgili spesifik semptomların varlığı metastaz için güçlü belirleyicilerdi.

SONUÇ: Kanserin tipi, metastaz sayısı, kilo kaybı, kötü performans status, kemik ve beyin metastazı yapan KHAK'lerinde semptomların olmamasının, karaciğer metastazında ise semptomların olmasının sağkalım oranları üzerine ters etkisi vardı. Hastaların klinik laboratuvar ve radyolojik bulguları bir bütün incelenmesi metazların tahmininde faydalı olurken, gereksiz cerrahiyi önlemiș olur.

Anahtar kelimeler: akciğer kanseri; metastaz; semptomlar; laboratuvar; sağkalım

\section{Introduction}

Cancer is the leading cause of death in economically developed countries and the second leading cause of death in developing countries ${ }^{1}$. In over two-thirds of patients, lung cancer is diagnosed at an advanced stage $^{2}$. This may reflect the aggressive biology of the disease, the frequent absence of symptoms until locally advanced or metastatic disease is present, and the lack, of an effective screening test. Symptoms may result 
from local effects of the tumor, from regional or distant spread. Distant metastatic disease is present at the time of initial diagnosis of lung cancer in approximately $43 \%$ of patients ${ }^{3}$. Brain, bones, liver, contralateral lung, adrenal glands are the most common sites of metastasis, but it can occur all over the body. It has been reported that the frequencies of extrathoracic metastasis of lung cancers are $54 \%$ in squamous cell carcinoma, $86 \%$ in large-cell and $82 \%$ in adenocarcinomas ${ }^{3}$.

Better understanding of the lung cancers' nature might help in two ways. First lung cancers may be identified early which is an important issue as treatment options change ${ }^{4}$. Secondly unnecessary surgery can be avoided since many patients have undetected disseminated disease at the time of thoracotomy, and this is the most likely cause of treatment failure and ultimate death ${ }^{5}$.

In this study, we investigated distant metastasis areas and the correlation of these metastases with cell type, organ-specific symptoms, physical examination and radiological findings and laboratory results in patients with lung cancer. With regard to these results, we evaluated the role of clinical assessment in predicting the distant organ metastases and also investigated the effect of metastases on life expectancy.

\section{Materials and Methods}

A retrospective computerized search of our center's clinical database for cases from January 2009 to September 2013 was used to identify 405 patients with a diagnosis of lung cancer as determined by means of cytologic and/ or histopathologic analysis of material. We excluded patients who did not have definitive histopathological diagnosis, or distant metastasis, patients whose staging tests were not completed and whose symptoms, signs and laboratory results could not be obtained. Final 174 patients with distant organ metastasis were chosen for the study. The tumor stage was defined according to the seventh revision of the tumor-node-metastasis classification ${ }^{6}$. Thoracic, cranial and abdominal computerized tomography (CT) and bone scintigraphy were used for staging. Symptoms, physical examination, radiological and laboratory findings associated with distant organ metastasis sites were evaluated.

Organ specific findings; in brain metastases, the presence of headache, dizziness, hemiparesis, gait and balance disorder, disturbance of consciousness, dysarthria, ptosis; in bone metastasis, localized pain, pathological fractures, dysfunction, hypercalcemia and high levels of ALP; in liver metastasis, hepatomegaly, elevated liver enzymes (AST, ALT, GGT), right upper quadrant pain, jaundice and ascites were evaluated.

Impact of cell type, location, number of metastasis, the presence of symptoms, weight loss, performance status, TNM stage on survival were evaluated.

\section{Ethical Concerns}

This retrospective study was approved by XXXX university Ethic Committee (2013.9.25) who waived the need for informed consent.

\section{Statistical Analysis}

The statistical analysis of the data were done by SPSS (Statistical Package for Social Sciences (SPSS) version 15.0 Chicago, Illinois). Defining characteristics of data were expressed as mean \pm standard deviation, numbers and percentages. Chi-square test was used for comparisons. Sensitivity, specificity, positive predictive values (PPV), negative predictive values (NPV) and likelihood ratios for bone, liver, brain metastases were calculated. Survival rates were calculated by Kaplan-Meier survival analysis of the groups. $\mathrm{P}<0.05$ was considered statistically significant.

\section{Results}

The study was performed on 158 (90.8\%) males and 16 (9.2\%) females who had lung cancer with distant metastasis at initial diagnosis. Mean age was 62.6 \pm 9.2 years (range: $33-81$ years). Demographic and clinical characteristics of patients with distant organ metastasis are shown in Table 1.

Squamous cell carcinoma (SCC) was the most common cell type (41.9\%). Distant metastases were most commonly found in bone (41.4\%). Bones in NSCLC and liver in SCLC were the most common sites of metastasis. The vertebrae (66.7\%) and then the ribs (50\%) were the most frequent bone metastasis sites. Adenocarcinomas for brain and bone, SCC for adrenal glands had predilection. While adrenal and brain metastasis were solitary, bone and liver metastases were often more than one. The frontal lobe was the most frequent $(59.1 \%)$ site of metastasis in the brain. Brain metastases tended to be solitary in NSCLC, while it was multiple in SCLC. The most frequent malignant pleural effusions were observed in adenocarcinomas. The breakdown in frequency of metastatic disease to specific sites according to histology was given in Table 2 .

Organ-specific symptoms and signs were not observed in $40.4 \%, 15.9 \%, 13.9 \%$, of patients with liver, brain 
and bone metastases respectively. Headache and dizziness for brain, localized pain for bone metastasis were the most common complaints. ALP levels were high in $73.6 \%$ of cases and it was significantly associated with the presence of bone metastasis $(\mathrm{p}=0.007)$. Hepatomegaly $(57.4 \%)$ was observed in patients with liver metastases, $70.2 \%$ of these cases had higher liver enzyme levels. AST, ALT and GGT elevation was significantly correlated with liver metastases, $(p=0.0001)$. There were no organ specific symptoms in patients with adrenal metastasis.

The presence of bone and brain-specific symptoms were shown to be more powerful in predicting metastasis

Table 1. Demographic and clinical characteristics of patients with distant organ metastasis

\begin{tabular}{lc}
\hline & $\mathrm{N}(\%)$ \\
\hline Gender & \\
Female & $16(9.2 \%)$ \\
Male & $158(90.8 \%)$ \\
Cell Type & \\
SCC & $73(41.9 \%)$ \\
Adenocancer & $36(20.7 \%)$ \\
Adenosquamos cancer & $1(0.6 \%)$ \\
Large cell cancer & $1(0.6 \%)$ \\
Unidentified NSCLC & $20(11.5 \%)$ \\
SCLC & $43(24.7 \%)$ \\
Metastasis locations & \\
Bone metastasis & $72(41.4 \%)$ \\
Liver metastasis & $47(27 \%)$ \\
Brain metastasis & $44(25.3 \%)$ \\
Adrenal gland metastasis & $34(19.5 \%)$ \\
Contralateral lung metastasis & $57(32.8 \%)$ \\
Pleural metastasis & $16(9.2 \%)$ \\
Other organ metastases* & $16(9.2 \%)$ \\
Organ specific symptoms and findings & \\
Patients with bone metastasis & $62 / 72(86.1 \%)$ \\
Patients with brain metastasis & $37 / 44(84.1 \%)$ \\
Patients with liver metastasis & $26 / 47(55.3 \%)$ \\
\hline ScC, squamous cell carcinoma; NSCLC, non-small cell carcinoma; SCLC, small cell carcinoma. \\
${ }^{*}$ Other organ metastases: pancreas, kidney, thyroid, stomach, intestine, soft tissue. \\
\hline
\end{tabular}

than any other organ specific symptoms. The absence of specific symptoms was not convenient for assessing the presence of liver metastasis. Weight loss of more than $10 \%$ was significant in the presence of bone and pleural metastasis $(\mathrm{p}=0.042, \mathrm{p}=0.034$ respectively).

Predicting the metastasis with presence of organ-specific symptoms in patients with bone, liver and brain metastases were shown in Table 3.

While primary lung tumors in the left upper lobe had predilection for brain metastasis, right upper lobe tumors had predilection for bone, liver, and adrenal metastases. In addition, central lung localization was accounted for the majority of metastases.

The median survival of all patients was calculated to be 198 days in the study. The longest median survival was in NSCLC with contralateral lung metastasis, the shortest was in SCLC with liver metastasis. The median survival according to localization of metastasis was shown in Table 4.

The survival time was 246 days in patients with single organ metastasis and 110 days in patients with multiple organ metastases $(p=0.003)$. The survival time in patients with NSCLC was 248 days in single organ metastasis and 120 days in multiple organ metastases and these figures were only 175 days and 81 days in patients with SCLC respectively. Relationship between survival and organ specific symptoms were shown in Table 5.

The survival was shorter in T3-4 group than in T1-2, in all study groups $(\mathrm{p}=0.014)$. There was no survival difference when N2-3 groups compared with N0-1 groups. However there was a significant survival difference found between M1a and M1b $(\mathrm{p}=0.01)$.

\section{Discussion}

This study showed that NSCLC in bone, brain and contralateral lung; SCLC in liver and adrenal gland

Table 2. The breakdown in frequency of metastatic disease to specific sites according to histology

\begin{tabular}{lccccccc}
\hline Cell type & $\mathrm{n}(\%)$ & $\begin{array}{c}\text { Brain } \\
\mathrm{n}(\%)\end{array}$ & $\begin{array}{c}\text { Liver } \\
\mathrm{n}(\%)\end{array}$ & $\begin{array}{c}\text { Bone } \\
\mathrm{n}(\%)\end{array}$ & $\begin{array}{c}\text { Adrenal gland } \\
\mathrm{n}(\%)\end{array}$ & $\begin{array}{c}\text { Contralateral lung } \\
\mathrm{n}(\%)\end{array}$ & $\begin{array}{c}\text { Pleural metastasis } \\
\mathrm{n}(\%)\end{array}$ \\
\hline SCC & & $17(9.8 \%)$ & $17(9.8 \%)$ & $28(16.1 \%)$ & $11(6.3 \%)$ & $24(13.8 \%)$ & $5(2.9 \%)$ \\
Adeno cancer & $36(41.9 \%)$ & $12(6.9 \%)$ & $3(1.7 \%)$ & $17(9.8 \%)$ & $5(2.9 \%)$ & $16(9.2 \%)$ & $5(2.9 \%)$ \\
Large cell & $1(0.6 \%)$ & $0(0 \%)$ & $0(0 \%)$ & $1(0.6 \%)$ & $1(0.6 \%)$ & $0(0 \%)$ & $0(0 \%)$ \\
Adeno ssquamous & $1(0.6 \%)$ & $1(0.6 \%)$ & $0(0 \%)$ & $0(0 \%)$ & $0(0 \%)$ & $0(0 \%)$ & $0(0 \%)$ \\
Unidentified SCLC & $20(11.5 \%)$ & $6(3.4 \%)$ & $6(3.4 \%)$ & $7(4 \%)$ & $5(2.9 \%)$ & $8(4.6 \%)$ & $3(1.7 \%)$ \\
SCLC & $43(24.7 \%)$ & $8(4.6 \%)$ & $21(12.1 \%)$ & $19(10.9 \%)$ & $12(6.9 \%)$ & $9(5.3 \%)$ & $3(1.7 \%)$ \\
Total & $174(100 \%)$ & $44(25.3 \%)$ & $47(27 \%)$ & $72(\% 41.4)$ & $34(19.5 \%)$ & $57(32.8 \%)$ & $16(9.2 \%)$ \\
\hline
\end{tabular}

SCC, squamous cell carcinoma; SCLC, small cell carcinoma. 
Table 3. Predicting the metastasis with presence of organ-specific symptoms in patients with bone, liver and brain metastases with help of Sensitivity, specificity, PPV, NPV

\begin{tabular}{lcccc}
\hline Organ specific clinical factors for & sensitivity & specificity & PPV & NPV \\
\hline Bone metastasis & $\% 86.1$ & $\% 91.7$ & $\% 86.1$ & $\% 91.7$ \\
Liver metastasis & $\% 59.6$ & $\% 93.8$ & $\% 75.7$ & $\% 87.7$ \\
Brain metastasis & $\% 84.1$ & $\% 87.2$ & $\% 66.1$ & $\% 94.9$ \\
\hline PPV, positive predictive value; NPV, negative predictive value. & & & \\
\hline
\end{tabular}

Table 4. Survival according to metastasis sites in NSCLC and SCLC

\begin{tabular}{|c|c|c|c|}
\hline & NSCLC & SCLC & \\
\hline Brain metastasis & 138 days & 81 days & \\
\hline Bone metastasis & 202 days & 168 days & \\
\hline Liver metastasis & 157 days & 65 days & $\mathrm{p}=0.017^{\star}$ \\
\hline Adrenal gland metastasis & 157 days & 118 days & \\
\hline Contralateral lung metastasis & 268 days & 175 days & \\
\hline
\end{tabular}

NSCLC, non-small cell carcinoma; SCLC, small cell carcinoma

Table 5. Relationship between Survival and Organ Specific Symptoms according to Brain-Bone and Liver Metastases in NSCLC and SCLC

\begin{tabular}{|c|c|c|c|c|}
\hline Metastasis sites & Symptom & NSCLC & SCLC & \\
\hline \multirow[t]{2}{*}{ Brain metastasis } & Yes & 164 days & 257 days & \multirow{2}{*}{$\mathrm{p}=0.0001^{\star}$} \\
\hline & No & 248 days & 125 days & \\
\hline \multirow[t]{2}{*}{ Bone metastasis } & Yes & 135 days & 224 days & \multirow{2}{*}{$p=0.002^{\star}$} \\
\hline & No & 248 days & 118 days & \\
\hline \multirow[t]{2}{*}{ Liver metastasis } & Yes & 198 days & 65 days & \multirow{2}{*}{$\mathrm{p}=0.005^{\star}$} \\
\hline & No & 219 days & 241days & \\
\hline
\end{tabular}

were the most frequently seen histologic tumor types. There were organ specific symptoms and signs in patients with bone and brain metastasis, however organ specific signs and symptoms were infrequent in liver and adrenal gland metastasis. The survival was shortened in patients who had symptoms and weight loss. Overall survival was shorter in SCLC than in NSCLC.

Many patients with lung cancer are in advanced stages of the disease at the time of diagnosis. The 5-year survival rate for patients with lung cancer is $10 \%$ to $20 \%$, as reported by Stanley ${ }^{7}$. Predicting tumor metastasis sites, understanding metastasis potential of lung cancer subtypes and organ specific symptoms and signs of metastasis may help diagnosing the disease earlier or preventing unnecessary thoracotomy in patients with advanced stage lung cancer.

Although there are some differences in SCLC and NSCLC in the terms of incidence and sites of metastasis; bone, liver, lung, brain and adrenal glands are the most common metastasis sites for both tumor type ${ }^{8}$. In our study, the most common distant metastases sites were bones (41.1\%), contralateral-lung $(32.8 \%)$, liver
(27\%), brain $(25.3 \%)$, adrenal (19.5\%), pleura (9.2\%). While the most common metastases site for NSCLC was bone and it was liver for SCLC.

It is reported that bone metastases from lung cancers occur in $14 \%$ to $40 \%$ of patients ${ }^{9}$. More than $80 \%$ of bone metastases are in the axial skeleton; vertebral column, ribs, pelvis and femur are the most frequently involved bones ${ }^{10,11}$. In a study, multiple bone metastases were seen in more than $84 \%$ of patients and the most frequent localization was the vertebrae, which was then the ribs ${ }^{9}$, while in another study it was the ribs $^{12}$. In our study, bone metastases tended to be in more than one location in both NSCLC and SCLC. The most common metastasis sites were spine (66.7\%) and then ribs (50\%). The most frequent clinical symptom in bone metastasis is localized bone pain ${ }^{11}$. In our study, the most common symptom was localized bone pain in $80.6 \%$ of cases. There was no pain in $13.9 \%$ of patients with bone metastases at all.

Brain metastases are found in about $10-25 \%$ of patients at the time of initial diagnosis, and approximately $40-50 \%$ of all patients with lung cancer develop brain 
metastasis during the course of their disease, with a greater frequency at autopsy (approximately 50\%) than predicted from the presence of symptoms ${ }^{13}$. The incidence of brain metastasis is increasing, mainly because of the longer patient survival times resulting from newer treatment modalities. Most patients with brain metastasis have multiple lesions ${ }^{14}$. Metastatic lesions are generally located in supratentorial region, especially in the frontal lobe ${ }^{14,15}$. In our study, brain metastases were detected in $25.3 \%$ patients, most often in the frontal lobe (59.1\%) and multiple brain metastases were present in $50 \%$ of cases. In patients with brain metastases; $70 \%$ of patients are asymptomatic and the most common symptom is headache. This is followed by focal sensory or motor loss, speech disorders and epileptic seizures ${ }^{16}$. In a study, there were no symptoms in the half the patients with brain metastases at initial diagnosis ${ }^{8}$. In our study, the most common symptom was headache $(45.5 \%)$ and $15.9 \%$ of patients did not have symptom at all.

Liver is one of the most common metastasis sites of lung cancers. In a study conducted in Japan, 5.8\% of lung cancer patients had liver metastases during the initial diagnosis and the most common histologic type was SCLC (45.2\%). Number of metastatic nodules in the liver were found to be more than one in $51.6 \%$ of patients ( $47.1 \%$ of patients with NSCLC, $92.8 \%$ of patients with SCLC) ${ }^{17}$. In our study, $27 \%$ of patients had liver metastasis, among them SCLC was the most common histologic type (42.5\%). The most of patients had multiple metastases (83\%). The disease specific signs and symptoms are infrequent in the early stages of liver metastasis but as the disease progresses, it may occur. Kagogash and colleagues identified the right hypochondriac pain in $8 \%$ of patients, irregular nodular liver growth in $3 \%$, jaundice in $3 \%$, the acid in $1.6 \%$ and liver enzymes elevation in $22.6 \%{ }^{17}$. In our study, hepatomegaly $(57.4 \%)$, jaundice $(4.3 \%)$, epigastric pain $(2.1 \%)$, and acid (2.1\%) were detected with descending order. Liver enzymes levels were high in $70.2 \%$ of patients with liver metastasis.

Adrenal metastases are often solitary, unilateral localized, small, asymptomatic lesions. Adrenal metastases are seen approximately in 3\% of lung cancer patients bilaterally ${ }^{18}$. In our study adrenal metastases were seen in $19.5 \%$ of cases and the most common histologic type was SCLC. Onesided settlement was found to be in $67.7 \%$ of the cases.

Pleural involvement is seen in $8-15 \%$ of cases ${ }^{18}$. There were pleural metastases in $16(9.2 \%)$ of patients in our study. Among them, pleural effusion was seen in
$13(7.5 \%)$ of cases which was the most commonly due to adenocancers $(n=5)$. There were contralateral lung metastases in $57(32.8 \%)$ patients. It was the most commonly seen in squamous cell carcinoma and then in adenocarcinoma.

Many studies have evaluated the value of organ specific and non-organ specific clinical factors that suggest extrathoracic metastases. The sensitivity, specificity, PPV and NPV have been reported to be $86 \%, 56 \%, \% 31$, and $95 \%$ respectively for abdomen, $76 \%, 82 \%, \% 52$, and $94 \%$ for brain and $82 \%, 62 \%, 32 \%$, and $90 \%$ for liver ${ }^{19}$. In our study, organ-specific symptoms in bone, brain, liver metastases had sensitivity of $86.1 \%, 59.6 \%$, and $84.1 \%$, specificity of $91.7 \%, 93.8 \%$, and $87.2 \%$, PPV of $86.1 \%, 75.7 \%$, and $66.1 \%$, NPV of $91.7 \%, 87.1 \%$, and $94.9 \%$ respectively. Our values were higher than previous studies. We think that organ specific symptoms, physical examination, laboratory findings are important as to show distant organ metastasis. Performing full investigation of extrathoracic metastasis is important so that unnecessary thoracotomy can be prevented.

It was shown that there is a strong correlation between the primary tumor localization, TNM stage and metas$\operatorname{tases}^{20}$. A study which investigated the brain metastases in NSCLC patients showed the predicted probability of metastatic disease to the brain was positively correlated with size of the primary tumor, cell type and lymph node stage but did not correlate with primary tumor location ${ }^{21}$. In another study showed that, liver metastasis was most frequently seen in centrally localized primary tumors and in T3-T4 and N $3^{17}$. In our study, the primary tumor was the most frequently located in the right upper lobe and the central location (63\%) in patients with distant organ metastasis. Also it was revealed that in the brain metastases, the primary tumor was the most frequently settled in the left upper lobe while it was the right upper lobe in bone, liver and adrenal metastasis. Accordingly with other studies, metastases were best correlated with T3-4 and N2-3 in our study.

In a study of 245 patients with advanced NSCLC in which $15.9 \%$ of them lived over 2 years showed that longterm survival was closely linked with having a metastases at fewer sites, an absence of bone metastases, a performance status (PS) of $0-1$, time to first progression of the tumour of $>3$ months, normal LDH levels at diagnosis and a haemoglobin concentration $>110 \mathrm{~g} / \mathrm{L}$ at first progression of the tumour ${ }^{4}$. In a study of 84 NSCLC patients presenting a solitary brain metastasis who underwent surgery have had calculated median survival of 9.7 months and survival 
was correlated with the tumor stage $e^{22}$. In our study the median survival time was 198 days and a significant correlation was observed between weight loss and survival. An increase in TNM stage and the number of metastases were correlated with decreased survival. Survival was shortened in patients with symptoms. Overall survival was shorter in SCLC than in NSCLC.

Limitation of this study; treatment modalities were not evaluated in the survival analysis. Since treatment modalities according to cell type, performance status and site of metastasis may cause differences in survival. However, number of patients was not enough for subgroup analysis according to different treatment modalities. More comprehensive studies on this topic are needed.

As a result patients who have primary tumor T3-4, lymph node metastases N2-3, weight loss, organ-specific symptoms and signs are more likely to have a metastasis. Organ-specific symptoms and signs may help in predicting metastases in patients with lung cancer, however it should not be forgotten that there might be metastases, even in patients who do not have signs and symptoms. In addition, survival in NSCLC and SCLC may vary according to location and number of metastasis and the presence of symptoms. Therefore, evaluation of all these factors by clinicians can help diagnosing the disease earlier and prevent unnecessary surgery.

\section{Financial/Nonfinancial Disclosures}

The authors have reported that no potential conflicts of interest exist with any companies/organizations whose products or services may be discussed in this article.

\section{Acknowledgements}

The manuscript has been read and approved by all authors and has never been published, or under the consideration for publication elsewhere. All person listed as authors have contributed to preparing the manuscript, and that no persons other than the authors listed have contributed significantly to its preparation. I would like thank you for your time in reviewing this submission. I would also be glad review other authors studies on the behalf your journal.

\section{References}

1. Jemal A, Bray F, Center MM, et al. Global cancer statistics. CA Cancer J Clin 2011;61:69-90.

2. Scagliotti GV. Symptoms, signs and staging of lung cancer. European Respiratory Monograph 2001;17:86-119.
3. Jemal A, Murray T, Ward E, et al. Cancer Statistics, 2005. CA Cancer J Clin 2005;55:10-30.

4. Giroux Leprieur E, Lavole A, Ruppert A-M, et al. Factors associated with long-term survival of patients with advanced non-small cell lung cancer. Respirology 2012;17:134-42.

5. Erturan S. The Role of Whole-Body Bone Scanning and Clinical Factors in Detecting Bone Metastases in Patients With Non-small Cell Lung Cancer. Chest 2005;127:449.

6. Detterbeck FC, Boffa DJ, Tanoue LT. The new lung cancer staging system. Chest 2009;136:260-71.

7. Stanley KE. Prognostic factors for survival in patients with inoperable lung cancer. J Natl Cancer Inst 1980;65:25-32.

8. Yamanaka R, Koga H, Yamamoto Y, et al. Characteristics of patients with brain metastases from lung cancer in a palliative care center. Support Care Cancer 2011;19:467-73.

9. Sugiura H, Yamada K, Sugiura T, et al. Predictors of survival in patients with bone metastasis of lung cancer. Clin Orthop Relat Res 2008;466:729-36.

10. Kosteva J, Langer C. The changing landscape of the medical management of skeletal metastases in nonsmall cell lung cancer. Curr Opin Oncol 2008;20:155-61.

11. Tsuya A, Kurata T, Tamura K, et al. Skeletal metastases in non-small cell lung cancer: a retrospective study. Lung Cancer 2007;57:229-32.

12. Mordant P, Arame A, De Dominicis F, et al. Which metastasis management allows long-term survival of synchronous solitary M1b non-small cell lung cancer? Eur J Cardiothorac Surg 2012;41:617-22.

13. Monnet I. Chemotherapy for small cell lung cancer with brain metastases. Bull Cancer 2013;100:89-93.

14. Paralkar VR, Li T, Langer CJ. Population characteristics and prognostic factors in metastatic non-small-cell lung cancer: a Fox Chase Cancer Center retrospective. Clin Lung Cancer 2008;9:116-21.

15. Soffietti R, Cornu P, Delattre JY, et al. EFNS Guidelines on diagnosis and treatment of brain metastases: report of an EFNS Task Force. Eur J Neurol 2006; 13:674-81.

16. Hochstenbag MMH, Twijnstra A, Hofman P, et al. MR-imaging of the brain of neurologic asymptomatic patients with large cell or adenocarcinoma of the lung. Does it influence prognosis and treatment? Lung Cancer 2003;42:189-93.

17. Kagohashi K, Satoh H, Ishikawa $\mathrm{H}$, et al. Liver metastasis at the time of initial diagnosis of lung cancer. Med Oncol 2003;20:25-8.

18. Karanikiotis C, Tentes AA, Markakidis S, et al. Large bilateral adrenal metastases in non-small cell lung cancer. World J Surg Oncol 2004;2:37.

19. Silvestri GA, Gould MK, Margolis ML, et al. Noninvasive staging of non-small cell lung cancer: ACCP evidenced-based clinical practice guidelines (2nd edition). Chest 2007;132:178S-201S.

20. Penel N, Brichet A, Prevost B, et al. Pronostic factors of synchronous brain metastases from lung cancer. Lung Cancer 2001;33:143-54.

21. Mujoomdar A, Austin JHM, Malhotra R, et al. Clinical Predictors of Metastatic Disease to the Brain from Non-Small Cell Lung Carcinoma: Primary Tumor Size, Cell Type, and Lymph Node Metastases. Radiology 2007;242:882-8.

22. Hu C, Chang EL, Hassenbusch SJ, et al. Nonsmall cell lung cancer presenting with synchronous solitary brain metastasis. Cancer 2006;106:1998-2004. 